\title{
Sentralisering og fødetilbud
}

\author{
Flere kvinner har fått lang reisevei til fødeavdeling, og risikoen for kom- \\ plikasjoner hos mor har økt.
}

Tilgjengelighet til fødeinstitusjon er én av flere viktige faktorer i god fødselsomsorg. Vi har nylig publisert en studie der sentraliseringen av norske fødeavdelinger beskrives (1). Den bygger på innbyggerdata fra Statistisk sentralbyrå for 2000 og 2010 og på fødselsdata fra Medisinsk fødselsregister for perioden 1979-2009.

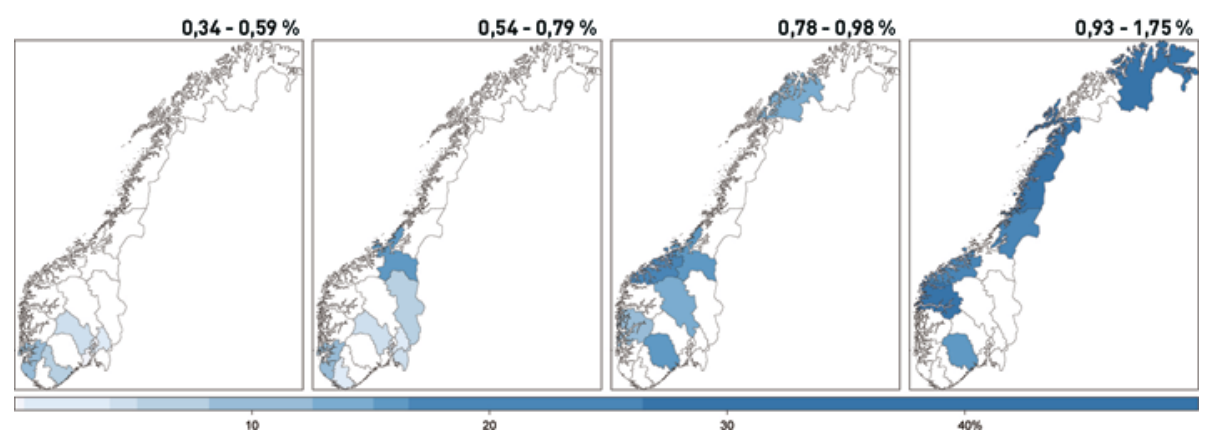

Risiko for ikke-planlagt fødsel utenfor institusjon og reiseavstand til fødeinstitusjoner. Fylkene er gruppert i fire ulike risikokategorier basert på perioden 2004-09. Fargeskalaen viser andel kvinner som bodde utenfor entimessonen i hvert fylke (\%) per 1.1. 2010 (data fra Medisinsk fødselsregister og Statistisk sentralbyrå, kombinert med data fra Norsk vegdatabank) (1)
Andelen kvinner i fertil alder som bodde mer enn 1-2 timer fra føde- eller akuttinstitusjon økte i alle regioner fra 2000 til 2010, med Møre og Romsdal som unntak. Økningen var størst i helseregionene Øst, Sør og Vest, mens helseregionene Vest, Midt-Norge og Nord hadde høyest andel kvinner bosatt langt fra fødeinstitusjon.

\section{Biologiske legemidler ved primært Sjögrens syndrom?}

\author{
Rituximab, et antistoff mot B-cel- \\ ler, hadde ingen sikker effekt ved \\ primært Sjögrens syndrom i en \\ randomisert, blindet studie.
}

Sjögrens syndrom er en plagsom, autoimmun tilstand som er vanskelig å behandle. Det finnes i dag ingen systemisk behandling som påvirker forløpet av primært Sjögrens syndrom. Bruk av rituximab, et antistoff mot B-celler, har vist lovende resultater, og er nå undersøkt $\mathrm{i}$ en randomisert multisenterstudie (1).

Studien omfatter 120 pasienter fra 14 universitetssykehus i Frankrike. Sykdomsgrad ble målt ved bruk av fire VAS-skalaer for global sykdom, smerte, utmattelse (fatigue) og tørre slimhinner. Pasientene ble randomisert til to infusjoner, gitt med to ukers mellomrom, med rituximab eller placebo. Seks måneder senere var det ingen forskjell mellom gruppene i primært endepunkt, som var andel pasienter som oppnådde en forhåndsdefinert reduksjon i minst to VAS-skalaer. Rituximabgruppen hadde imidlertid signifikant reduksjon i VAS-skår samt mindre sykdomsaktivitet vurdert av lege etter seks uker og redusert utmattelse etter både seks og 16 uker.

- Det er en god studie fordi den er blindet og omfatter mange pasienter fra flere sentre, sier Roald Omdal, spesialist i indremedisin og revmatologi og professor ved Stavanger universitetssjukehus. - Svakheten er at effekten ble evaluert seks måneder etter bare to infusjoner med rituximab. Tilsvarende studiedesign og effektmål er blitt kritisert i studier ved systemisk lupus erythematosus, der man heller ikke så noen
Risikoen for ikke-planlagt fødsel utenfor institusjon er økt i alle fylker de siste 30 årene og ble doblet på landsbasis. Det var økende geografisk ulikhet, med høyest risiko i fylker med lengst reiseavstand. Mors risiko for alvorlige komplikasjoner økte fra $1,7 \%$ til 2,2\% fra 2000 til 2009 (oddsratio 1,$4 ; 95 \%$ KI 1,2-1,5), og i 2009 var det signifikante regionale forskjeller.

Studien viste ikke gevinst av sentraliseringen av fødselsomsorgen i form av redusert risiko for alvorlige komplikasjoner hos mor, slik man kunne forvente. Flere studier, der også barnets helse må tas med, er nødvendig. Økende geografiske forskjeller krever bedre kunnskap om fordelingen av nytte og ulemper ved sentralisering av fødselsomsorgen.

\section{Hilde Marie Engjom}

Forskningsgruppe for globale helseprioriteringer, Institutt for global helse og samfunnsmedisin Universitetet i Bergen

Litteratur

1. Engjom HM, Morken NH, Norheim OF et al. Availability and access in modern obstetric care: a retrospective population-based study. BJOG 2014; 121: $290-9$. effekt av rituximab. Ved begge disse sykdommene viser klinisk erfaring at rituximab kan ha effekt, og andre studier peker i denne retningen.

- At pasientene i denne studien følte seg mindre utmattet $\mathrm{i}$ noen måneder, passer godt med studier der biologiske legemidler er brukt mot autoimmune og inflammatoriske sykdommer. Virkningsmekanismen kan være at midlene reduserer utskilling av proinflammatoriske cytokiner, sier Omdal.

\section{Kari Tveito}

Tidsskrifte

Litteratur

1. Devauchelle-Pensec V, Mariette X Jousse-Joulin $S$ et al. Treatment of primary Sjögren Syndrome with rituximab. A randomized trial. Ann Intern Med 2014; 160: 233-42. 